DOI: $10.30520 /$ tjsosci. 872121

\title{
YEREL KATILIM AÇISINDAN KENT VE KENTLİ KIMLİĞİ, KENTSEL AİDIYYT VE KENTSEL FARKINDALIK DÜZEYİ: BATMAN ÖRNEĞİ
}

\author{
URBAN AND URBAN IDENTITY IN TERMS OF LOCAL PARTICIPATION, URBAN \\ BELONGING AND LEVEL OF URBAN AWARENESS: THE CASE OF BATMAN
}

\section{Muzaffer BİMAY ${ }^{1}$}

\section{ÖZET}

Kentin ortaya çıkışı milattan öncesine dayanmasına rağmen kent ve kentli kimliğinin oluşturulması ve kentsel aidiyet ilişkisinin kurulması, kentsel katılım mekanizmalarının hayata geçirildiği 19. yüzyıla dayanmaktadır. $\mathrm{Bu}$ dönem, modern anlamda kentin tanımlandığı, kentin kentliler tarafından sahiplendiği, demokratik yerel yönetim ve katılım mekanizmalarının ortaya çıktığı, yerel kimliklerin farkına varıldığı sanayileşme sonrası dönemdir. Ancak sanayileşme sonrası kentlerin, sosyo-ekonomik ve kültürel olanakları sayesinde maruz kaldığı yoğun nüfus hareketleri nedeniyle kent ve kentli kimliğini korumak, yerel halkın kentsel aidiyet ve farkındalık düzeylerini diri tutmak gittikçe güçleşmiştir. Bu nedenle kentte yaşayanların, kentli hakları açısından, kentsel aidiyet duygusunu ve kentsel farkındalık düzeyini geliştirilebilmeleri için kente özgü davranış biçimlerini benimsemeleri ve yerel yönetim mekanizmalarında katılım olanağı bulmaları gerekir. Buradan hareketle yapılan bu çalışmanın amacı, son yüzyılda hızlı bir kentleşme süreci geçiren Batman' da, kentte yaşayan bireylerin yerel katılım ve kentsel hakları kullanmaları açısından kentsel aidiyet duygularını ve farkındalık düzeylerini incelemektir. $\mathrm{Bu}$ bağlamda yapılan saha araştırmasında nicel araştırma yöntemi kullanılarak araştırmanın hedef evrenini oluşturan ve Batman kentinde yaşayan kişiler içinden 18 yaşından büyük 238 katılımcı ile anket yapılmıştır. Anketler 2020 yılı içerisinde uygulamalı bir alan araştırması şeklinde gerçekleştirilmiştir. Araştırmaya katılan katılımcıların çoğunun çocukluk veya gençlik yıllarını geçirdikleri Batman'da, kentsel haklar bağlamında kentlilik bilincine sahip oldukları ve kentsel hakların farkında oldukları, ancak yerel katılım mekanizmalarının işlevsizliğinden kaynaklanan yetersiz katılım olanakları nedeniyle bu hakları kullanmada sorun yaşadıkları ortaya çıkmıştır. Dolayısıyla kent ve kentli kimliği açısından çoğu katılımcının kentsel aidiyet duygularının gelişmediği de söylenebilir. Çalışmada ayrıca kentsel bilinç düzeyinin geliştirilmesi için kentsel hakların kullanılmasına yönelik katılım olanaklarının genişletilmesi gerektiği de vurgulanmıştır.

Anahtar Kelimeler: Kent, Kentli Kimliği, Yerel Katılım, Kentsel Aidiyet, Kentsel Farkındalık

\footnotetext{
${ }^{1}$ Öğr. Gör. Dr., Batman Üniversitesi SBMYO, muzafferbimay@gmail.com, Orcid: 0000-0002-6742$\underline{2852}$
} 


\begin{abstract}
Although the emergence of the urban dates back to B.C., the creation of the urban and urban identity and the establishment of the relationship of urban belonging were implemented in the 19th century, when urban participation mechanisms were implemented. based on the century. This period is the postindustrialization period in which the urban was defined in the modern sense, the urban was owned by the urbanites, democratic local government and participation mechanisms emerged, and local identities were realized. However, due to the intense population movements that post-industrialization urbanies are exposed to due to their socio-economic and cultural opportunities, it has become increasingly difficult to maintain the identity of the urban and the urban population, and to keep the local population alive with their level of urban belonging and awareness. For this reason, residents of the urban should adopt urban-specific behaviors and find the opportunity to participate in local government mechanisms in order to develop a sense of urban belonging and a level of urban awareness in terms of urban rights. Based on this, the aim of this study is to examine the feelings of urban belonging and awareness levels in Batman, which has undergone a rapid urbanization process in the last century, in terms of local participation and the exercise of urban rights of people living in the urban. In this context, 238 participants over the age of 18 were surveyed among the people who made up the target universe of the study and lived in the urban of Batman using the quantitative research method in the field research conducted. The surveys were conducted in the form of an applied field survey in 2020. In Batman, where most of the participants in the study spent their childhood or teenage years, it was found that they were urban conscious and aware of urban rights in the context of urban rights, but had problems exercising these rights due to insufficient participation opportunities caused by the dysfunction of local participation mechanisms. Therefore, in terms of urban and urban identity, it can also be said that most participants ' feelings of urban belonging do not develop. The study also emphasized the need to expand participation opportunities for the use of urban rights in order to improve the level of urban awareness
\end{abstract}

Keywords: Urban, Urban Identity, Local Participation, Urban Belonging, Urban Awareness

\title{
Giriş
}

Beş bin yıllık bir geçmişi olan kent olgusunun modern anlamda bilime konu olması, nüfus artışına bağlı olarak ortaya çıkan kentleşme süreçlerinin hızlandığı ve Batı'nın tarihi evrimine özgü bir aşamaya geldiği 18. ve 19. yüzyıldaki Sanayi Devrimi’yle birlikte gerçekleşmiştir (Vergin, 1986:27). 1800 yılında dünya nüfusunun yaklaşık \% 3'ü kentlerde yaşarken, günümüzde bu oran \% 55'in üzerine çıkmıştır. Türkiye'de ise bu oran \%92'lerin üzerinde seyretmektedir. 2050 yılında dünyada ve ülkemizde daha da artması beklenilen bu oran (Bimay, 2020:6216) karşısında kentlerin sürdürülebilir olması ve toplumsal uyum dengesinin sağlanabilmesi için kentleşme süreçleriyle birlikte kentlileşme denilen kente ait davranış kalıplarının benimsenmesi ve kente sahip çıkan bireylerin ortaya çıkması gerekmektedir. Bunun için kent kültürünü ve kentsel davranış kalıplarını benimseyen ve yerel katılımda aktif olarak yer alan kentli kimliğine sahip bilinçli bireylere ihtiyaç duyulmaktadır. Kentli kimliği, kentte yaşayanların yerel katılım mekanizmalarına katılım oranları ile ölçülür. Yerel düzeyde demokrasinin gerçekleşebilmesi için halkın bilgisinin önemsenmesi, karar alma süreçlerine katılımının sağlanması ve diğer yerel aktörlerle birlikte yerel katılım mekanizmalarını denetleyebilmesi gerekmektedir. Kentte yaşayanlar, yönetişim kültürü içerisinde yerel katılım mekanizmalarında ne kadar etkili olurlarsa kentsel aidiyet duyguları ve kentli kimlikleri de o ölçüde gerçekleşmiş olur.

21. yüzyılda, ulus devletlerin kentleri merkezileştirmesine karşın küreselleşme dinamiklerinin yerelleşmeyi ön plana çıkartması, kentlerde katılım, aidiyet duygusu, farkındalık düzeyi ve heterojen kavramlarının önem kazanmasını sağlamıştır. Böylece kent yaşamında yerel figürlerin ön plana çıktığ1, yerel halkın bilgi ve desteğinin önemsendiği, katılım mekanizmalarının sundukları olanaklar sayesinde her düzeyde katılımın sağlandığı yeni bir yaklaşım ortaya çıkmış oldu. Bu çalışma, bu yaklaşım çerçevesinde yerel katılım bağlamında 
kent ve kentli kimliğini ele almakta ve Batman özelinde kentsel hakların kullanımına ilişkin kentlilerin aidiyet duygularını ve farkındalık düzeylerini incelemek amacıyla elde edilen bulgularını analizini yapmaktadır. Dolayısıyla bu çalışma ile bilgi birikimine bağlı olarak kentsel sorunlara duyarlılık gösteren, çözüm yolları geliştiren, şimdiki ve gelecek nesillere sosyo-ekonomik, çevresel ve kültürel açıdan daha sağlıklı bir kent bırakma konusunda kentine sahip çıkan ve bu bilinçte hareket eden bireylerin varlığı sorgulanmaktadır. Bu bağlamda yapılan nicel araştırma yöntemiyle elde edilen bulgular betimsel analiz yöntemiyle yorumlanmıştır. Yapılacak saptamalar ve elde edilecek bulguların gelecekte kentlerle ilgili olarak oluşturulacak yerel politikalara yol gösterici olması ümit edilmektedir.

\section{Kent Terminolojisi}

İnsanoğlunun yerleşik hayata geçmesiyle birlikte oluşan ve geçmişinin Paleolitik ve Neolitik dönemlere kadar uzandığı düşünülen kentin, sosyolojik açıdan ele alınması, 18. ve 19. yüzyıldaki gelişmelere bağlı olarak gerçekleşmiştir. Bu dönemde kent kavramı, geleneksel anlamındaki işlevinden koparılarak, ekonomik, sosyo-kültürel ve bilgi teknolojisine dayanan değerlerin katılmasıyla yeni anlamlar kazanmıştır. Bu yeni anlamlar çerçevesinde kent yazınında kentin ortaya çıkışı ve kentin tanımına ilişkin birçok kuram ortaya atılmıştır. Bu kuramların başında kenti, ekonomik, dini, hukuki, askeri güç, toprağın değeri ve iklim koşulları gibi tek yönlü olgularla açıklayan Henri Pirenne ve İbn-i Haldun gibi kuramcıların ortaya koyduğu kuramlar gelmektedir (Aslanoğlu, 2000:21). Bunlardan başka, kentleri kır ve kent, sanayi öncesi ve sanayi kenti, geleneksel ve modern, feodal, kapitalist ve Komünist üretim tarzına sahip kent şeklinde belirli sınıflandırmalar üzerinden açıklayan Gideon Sjoberg, René Maunier, Ferdinand Tönnies, Emile Durkheim, Herbert Spencer, Max Weber, George Simmel, Karl Marx, Friedrich Engels ve Chicago Okulu'nun da dahil olduğu klasik kuramcılar da bulunmaktadır (Saunders, 2013). Ayrica 1960'lardan itibaren başta Henri Lefebvre David Harvey ve Manuel Castells'in olduğu birçok kuramcı kentsel gelişmeyi eleştirel bir bakış açısıyla ele alarak kent bilimine önemli bir katkı sağlamışlardır. Bu eleştiriler özetle; kent hakkı çerçevesinde kentin düzensiz ve kuralsız bir şekilde büyümenin ötesinde bir olgu olduğunu ve bu olguyu yeni üretim ilişkilerin mekânı olarak görmek gerektiğini belirtmekte (Lefebvre, 2013), sermeyenin dolaşım süreci ile kent mekânı arasındaki ilişkiyi ortaya koymakta (Harvey, 2012) ve kentleri, içinde devletin de olduğu kolektif tüketimin mekânı olarak kentlerin demokratik yönetimini savunmaktadır (Castells, 2014).

Literatürde kent kavramı için geliştirilen tanımlar, bu teoriler ışı̆̆ında oluşturulmuştur. Örneğin Weber, kenti bir evler topluluğuna sahip olmasının yanında toprağa dayalı sahip olunan mülkiyet, gelir ve giderlerden oluşan bir bütçesiyle aynı zamanda ekonomik bütünlüğe sahip bir birim olarak (Weber, 2003:94) tanımlamaktadır. Ortaylı ise kenti, civar yerleşmelerin ekonomik faaliyetlerini denetleyen, uzmanlaşmaya dayalı üretimi gerçekleştiren ve bunun sonunda toplumsal ve yönetsel açıdan da çevresi üzerinde kontrol mekanizması görevi üstlenen yerleşim birimi (Ortaylı, 1974:194) olarak idari açıdan açıklamaktadır. Maunier ise kenti, sanayi ve ticaretin gelişmesine bağlı olarak ortaya çıkan ve uzmanlaşmaya dayalı üretim biçimiyle yapısı şekillenen ve morfolojik kriterlere göre evrensel ölçütler geliştirilen mekanlar (Maunier, 1910:541-545) olarak ifade etmektedir. Dolayısıyla farklı kuramlar çerçevesinde ele alınan kent olgusunun geleneksel sanayi öncesini kapsayan tanımlardan sıyrılarak, küreselleşme ve yerelleşme dinamikleri içerisinde yerel katılım mekanizmalarının var olduğu ve bilgiye dayalı üretimin gerçekleştiği mekânlar olarak tanımlamak, günümüz kentlerini anlamlandırmada daha işlevsel kılacaktır. Bu şekilde kent, bireylerin özgür olarak ortaya çıktığ heterojen bir toplum yapısının olduğu, demokrasiden, laik düşünceden, siyasal, dinsel, sanatsal 
hoşgörüden, bilimsel bilgi ve nesnellikten oluşan bir kültürün yaşandığı, ekonomik ve sosyokültürel yapının kurumsallaştığı yerler olarak kabul edilmektedir (Bimay, 2019:61).

Kentlerin nüfus ve alan açısından büyümesi olarak kentleşme, nüfusun büyük oranda tarımdan ve topraktan kopup tarım dışı alanlarda, hayatlarını kazanmaya ve yaşamaya başlamalarıdır (Kıray, 1982:57). Kentleşme, kentlerin büyümesiyle birlikte ortaya çıkan yaşam biçiminin belirgin özelliklerinin ve kentin kurumlarıyla kentlilerin, iletişim, ulaşım araçları sayesinde oluşturduğu büyünün etkisi altında kalan bireylerde, kentli olarak kabul edilen yaşam biçiminin niteliğindeki değişmeleri açıklar (Wirth, 2002:79). İnsanoğlunun var oluşu kadar eski olmasa $\mathrm{da}$, kentin oluşma süreciyle beraber ortaya çıkan ve yaşanılan alanların genişleme süreci olarak ta tanımlanan kentleşme (Ozankaya, 1975:63), kentlerde meydana gelen ekonomik, sosyal, kültürel ve demografik değişim ve yoğunluğa bağlı olarak ortaya çıkan bir süreçtir (Gökçe, 1977:8). Devletin de belirli bir takım faaliyetlerini gerektiren bu değişimler, kentte yaşayanların tüm davranışlarını etkilemektedir (İsbir, 1982:7-9). Böylece kentte yaşayanların kentsel yaşam kalıplarını benimsemesi ve kültürel norm ve kurallara uyması (Kaypak, Bimay ve Yılmaz, 2019:184), ekonomik, siyasal ve kültürel süreçleri kesintisiz ve bütünleşmiş olarak yaşamas1 kentleşme süreçlerini olumlu k1lmaktadır (Sezal, 1997:147).

Kentte yaşayan herkes kentli kimliğine kavuştuğu söylenemez. Kent yaşantısıyla uyum kuramamış, kentle bütünleşememiş bireyler, kentli haklardan yeterince yararlanamayan kentli nüfus sorununu ortaya çıkartmıştır (Şenyapılı, 1981:25-26). Dolayısıyla insanların kent ile bütünleşmesini ifade eden kentlileşme kavramı, kentleşme sonucunda toplumda meydana gelen değişmelerin insanların davranışlarında ve ilişkilerinde değer yargılarında maddi ve manevi yaşam şekillerinde değişiklikler meydana getirme sürecidir (Es ve Ateş, 2004:215). Kentlileşme birey ölçeğinde hukuksal, yönetsel, sosyo-ekonomik ve kültürel bir değişim olarak kabul edilir. Bu değişim, toplumsal olarak yaşanan kentleşme sürecinin birey ölçeğindeki yansimasidir (Erkut, 1991:52).

Kentlileşme süreciyle birlikte ekonomik ve sosyal yönleriyle kır insanı kırın özelliklerinden arınarak kentin özelliklerini taşıyan kent insanına dönüşmektedir (Kartal, 1983:95). Bu süreç, ekonomik ve sosyal bakımdan olmak üzere iki şekilde gerçekleşir. "Ekonomik bakımdan kentlileşme" kişinin geçimini tamamen kentte veya kente özgü işlerde sağlar bir hale gelmesiyle gerçekleşir. "Sosyal bakımdan kentlileşme" ise, kır kökenli insanın türlü konularda kentlere özgü tavır ve davranış biçimlerini, sosyal ve tinsel değer yargılarını benimsemesi ile gerçekleşir (Kartal, 1983:92-95). Dolayısıyla, kentlileşme salt şehrin demografik yapısını değiştirme anlamında algılanmamalı aynı zamanda pozitif anlamda bir uyum şartı oluşturmalıdır (Bimay, 2016:87). Böylece kentlileşme ile bireylerin kentlilik bilincini ve kentli kimliğini elde etmeleri, hak ve sorumluluklarının farkında olmaları da sağlanmış olacaktır.

\section{Kentlerin Tarihsel Gelişim Süreci}

Kentlerin ortaya çıkışıyla ilgili kesin bilgilere sahip olunmamakla beraber (Eke, 1982:6), genel olarak tarımsal üretimin başarılı yönetildiği Mezopotamya ve Kuzey Afrika'da M.Ö. 3000 yıllarında ortaya çıktı̆̆ 1 belirtilmektedir (Huot, Thalmann ve Valbelle, 2000:28). Kentsel devrimin yaşandığ 1 , örgütlü, kurumsal ve hiyerarşik bir kent tipinin ortaya çıktığ 1 ilk ana mekan ise Güney Mezopotamya'nın Uruk yerleşimi olduğu ileri sürülmektedir (Childe, 2006:104107). $\mathrm{Bu}$ dönemden itibaren oluşturulan ve gün geçtikçe büyüyen kent merkezlerinin sürdürülebilir hale gelebilmesi için zamanla bu merkezlerde siyasi bir otoritenin kurulmasına ihtiyaç duyulmuştur (Spellman, 2011:10). Ancak bu otorite, yerel halkın katılımına dayanan günümüz modern kentin yapısından farklı bir yapı olarak ortaya çıkmıştır. 
Ortaçağ'da kentler, ticari ve komün sistemine dayalı bağımsız bölgeler olarak ortaya çıkmış olsa da Batı'da ve Doğu'da dini çevrelerin etkisinden kurtulamamışlardır (Pirenne, 2000:53). $\mathrm{Bu}$ dönemde kentler, Rönesans ve sonrasında mutlakiyetçi devletin etkisiyle bürokrasi ve ordunun gücünü temsil eden planlı geniş bulvarlar ve meydanların yer aldığı mekânlar olarak karşımıza çıkmıştır (Mumford, 2013:455). 18. yüzyıldan itibaren başta İngiltere olmak üzere birçok Avrupa ülkesinde, Sanayi Devrim'inin de etkisiyle, endüstriyel bölgelerin kentlerin etrafinda yoğunlaşmasıyla kentler genişlemeye başlamış (Sjoberg, 2002:41) ve modern bir yönetim organizasyonuyla ortaya çıkmıştır. Özellikle kırsal nüfusun kent merkezlerine doğru akın etmesi, iletişim ve ulaşım teknolojisinde meydana gelen gelişmeler kentlerin fiziksel mekânının biçimlenmesinde ve kademelenmesinde etkili olmuş ve kentler, sosyal, ekonomik, kültürel ve siyasal dönüşümlerin mekânı haline gelmiştir (Çınar, Çiner ve Zengin, 2009:13). Kırsaldan kentlere yoğun yaşanan bu göç akımları sonucu başta sanayi kenti Londra olmak üzere Paris ve Newyork gibi birçok kentte yeni yönetim anlayışları ön plana çıkmıştır (Frey ve Zimmer, 2001:25-28). Yerel katılıma dayanan bu yönetim anlayışları, 19. yy’den itibaren ulusdevletin dayattığı tekçi devlet anlayışının güçlenmesine bağlı olarak kentlerin özgürleşmesiyle var olmuştur (Ortayl1, 1995:138). Ancak kentlerin asıl ön plana çıkması kapitalizmin krizleriyle birlikte ulus devletin gerilemeye ve dönüşmeye başlaması (Apan, 2016:3) ve yerelin ön plana çıkmasıyla gerçekleşmiştir. 1990'lardan sonra yönetişimci ve girişimci kent modelleri ortaya çıkmış ve rekabetçi kent anlayışı genişlemeye başlamıştır (Çınar, Çiner ve Zengin, 2009:2025). Günümüzde ise kentler, bireyi önemseyen, bireyin tüm katılım mekanizmalarında yer alması için olanaklar sunan, kişisel ve kolektif haklara kavuşma imkânının elde edildiği önemli mekânlar olarak varlığını sürdürmektedir.

\section{Kentsel Katılım Bilinci ve Kentli Kimliğinin Kazandığı Anlam}

Kentlerin demokrasi kavramıyla birlikte anılmasının temelinde, Antik Yunan kentleri yatmaktadır. Ancak günümüz yerel katılım anlayışına dayalı kentlerin varlığ 1 , 20. yüzyılın sonu ve 21. yüzyılın başlarında, küreselleşme ve yerelleşme sonucunda toplumsal anlamda yaşanan değişim ve dönüşümlere bağlı olarak uluslararası aktörlerin kentleri önemsemesi ile ortaya çıkmıştır. Kentli kimliğin oluşmasında ve kentsel hakların sağlanmasında başta BM ve AB olmak üzere uluslararası aktörlerin girişimleri etkili olmuştur. 1976 yılında Kanada'da yapılan ve insan yerleşmeleri ile çevre ilişkisini ela alan HABİTAT 1 ve 1996 y1lında sürdürülebilir kentleşme ve insan yerleşmelerinin önemini belirtmek amacıyla İstanbul'da yapılan HABİTAT II Konferansı'nda (Kaypak vd., 2019:186) kenti sahiplenme ve aktif katlımı hayata geçirme adına "herkes için yeterli konut" ve "dünyada sürdürülebilir insan yerleşmelerinin gelişmesi" konuları üzerinde durulmuştur (Tosics, 1996:368). Avrupa Konseyi tarafindan kentlerde özerk yönetimlerin oluşturulmasına yönelik 1985 yılında yürürlüğe konulan Avrupa Yerel Yönetimler Özerklik Şartı, kentli haklarının oluşturulması bakımından Avrupa Yerel ve Bölgesel Yönetimler Kongresi tarafindan 1992 yılında kabul edilen Avrupa Kentsel Şartı I ve aynı yıl Rio'da yapılan konferansta "Yerel Gündem 21" ve "Yeryüzü Şartı" adıyla yayımlanan iki önemli sonuç bildirgesiyle kent, bütüncül bir şekilde ele alınmıştır. Rio Zirvesinde kabul edilen Gündem 21'in gelişim sürecini değerlendirmek amacıyla 1997 yılında yapılan Rio +5 zirvesinden sonra, 2000 yılında Binyıl (Milenyum) Zirvesi düzenlenmiştir. Bunların dişında Birleşmiş Milletler Çevre Programı (UNEP), Johannesburg Konferansı (2002), Kentsel Forumları (2002,2006,2010,2012), 2008 y1lında kabul edilen Avrupa Kentsel Şartı II, Rio +20, Birleşmiş Milletler Sürdürülebilir Gelişim Konferansı (2012) kentlerin iyileştirilmesine ve yeni bir anlayış içerisinde sürdürülebilir kılınmasına önemli katkı sağlamıştır (Kaypak vd., 2019:186). Uluslararası alanda kentlerin sürdürülebilir kılınması ve kentsel hakların elde edilmesine yönelik çabalar ülkemizde ki kentleri de etkilemiştir. Türkiye'de özellikle 1980'lerden itibaren küreselleşme ve yerelleşmeye bağlı olarak katılım mekanizmalarının 
yerelde önem kazanması ve kentsel hakların uluslararası alanda kullanılmaya başlanmasıyla kentin önemi artmaya başlamış ve kent ile ilgili mevzuatın geliştirilmesiyle uluslararası gelişmelere uyum sağlanmıştır.

Küreselleşme ile birlikte son dönemlerde ortaya çıkan teknolojik devrim ve neo-liberalizmle gelen kapitalist yönetim anlayışındaki ani dönüşüm, devletçiliğin ortadan kalkmasının yanında kozmopolitleşmeye karşı kültürel tekilliğe ve yerel özgünlüğe dayalı yeni bir yaklaşımı da ortaya çıkartmıştır. Bu yeni yaklaşım, insanların kendilerini ve çevrelerini denetlemeleri adına güçlü kolektif kimlik ifadelerinin artışını ifade eden yerel katılımı önemseyen ve çoğulcu yeni bir süreç olarak kendini ifade etmiştir (Castells, 2006:4). Bu süreç, aynı zamanda yeni mekânsal hareketliliklerin yaşanmasına ve bilgiyi toplumun uyum süreçlerinde yeni bir sorunsal alanın ortaya çıkmasına imkân sağladı (Tekeli, 1998:8). Bu sorunsal alanın içerisinde kentsel kültürü benimseyen, kente aidiyet hisseden ve kentsel haklarını bu çerçevede kullanan demokratikleşmeye dayalı katılımcı birey ortaya çıktı. Esasında bu yeni süreçte özgürleşen bireyin olduğu kentler, sorumluluk almaktan kaçınan kentliler, aidiyetsizlik ve artan yabancılaşma nedeniyle ortak hareket etmenin gittikçe zorlaştığı mekanlar haline geldiği de ileri sürülmüştür. Ancak bilgi ve iletişim teknolojilerindeki akıl almaz gelişmelerin meydana getirdiği bilgi toplumu, küreselleşme ile sermayenin ve ticaretin serbest dolaşımı ve küresel bütünleşmenin öngördügü standart ve normların evrensel değer olarak kabul görmesi kente özgü yeni insan ilişkilerini ortaya çıkarttığı yadsınamaz bir gerçektir. Kentlilerin evi ile işi dışında kalan gri alanda kentlilerin yaşamını kolaylaştıracak kültür, sanat ve boş zamanlarını geçireceği diğer aktiviteleri zenginleştiren alanlar aynı zamanda kentli kimliğini meydana getirmiştir (Tatlıdil, 2009:320). Kişilerin kent ile kurdukları bu ilişki ve zamanla aidiyet duygusunu içeren kentsel kimliğin oluşumu tarihsel bir olgu olarak nitelendirilmektedir (Tekeli, 1991:83). Bu yeni süreçte, kentte yaşayan yurttaş, daha fazla hizmet talep eden ancak yönetsel faaliyetlerle daha az ilgilenmek isteyen rasyonel bir tüketiciye dönüşmektedir (Bauman, 2000). Kentlerdeki bilinçli ve bilgili bireyler, kentteki varlığını sorgulamakta, yaşadığı çevreyi gözlemlemekte ve onun biçimlendirilmesi sürecine katkıda bulunmaktadır. Böylece katılım olanaklarını rasyonel şekilde kullanan bu kentliler, kentsel yaşam kalitesinin yükseltilmesinde ve kentleri yaşanabilir mekânlara dönüştürmekte önemli rol oynamaktadırlar (Batmaz ve Gürer, 2017:1634). Dolayısıyla toplumun sosyo-kültürel yapısını oluşturan toplumsal deneyimler, görüşler, inançlar ve davranışlar kentsel kimliğin oluşmasında bütüncül bir etki yaratmaktadır (Beyazit vd., 2013:154-155).

Kent ve kentli kimliği; sosyo-ekonomik, kültürel, fiziksel, tarihsel ve biçimsel faktörlerle biçimlenen, kent imajını etkileyen, onu sürdürülebilir kılan uzun soluklu birey davranışlarıdır. Kentlilik bilinci, kent ve kentli kimliğinin oluşmasında önemli bir role sahiptir. Kentsel aidiyet, kenti sahiplenme, kent sorunlarıyla ilgilenme, kent kurumlarına katılım ve kentsel farkındalık ölçütleri ile gerçekleşmektedir (Mutlu ve Batmaz, 2013). Kentli kimliği, bireyin kent ile olan etkileşiminden kaynaklanan duygusal bağl1lık ve aidiyet duygusu ile meydana gelir. Bireyin kamusal ve yerel katılım mekanizmalarındaki söz sahipliği, kentteki yönetişim alışkanlıkları, çevre duyarlığ 1 gibi özellikler bu kimliğin oluşmasında önemli etkenler olarak karşımıza çıkmaktadır. Şeffaf ve yönetişime dayalı yönetim anlayışıyla katılımcı demokrasiyi ön plana çıkartan kentlerde, yerel düzeyde demokrasinin gerçekleşmesi için yerel yönetimlerin özerkliğinin yanı sıra yerel sivil örgütlenmelerin (sendika, dernek, vakıf vs.) ve halkın da karar alma süreçlerine etkin ve aktif bir şekilde katılması ve onları denetleyebilmesi gerekmektedir. Bunun için de vatandaşların bilgisi ve ilgisinin de önemsenmesi gerekmektedir. Ayrıca yerelde vatandaşın aktif katılımı, vatandaş ile yönetim arasındaki kopukluğun giderilmesini ve toplumsal öz güvenin artırılmasını sağlayarak demokratik anlayışın gelişmesine katkıda bulunacaktır (Bulut ve Bimay, 2019:53). 


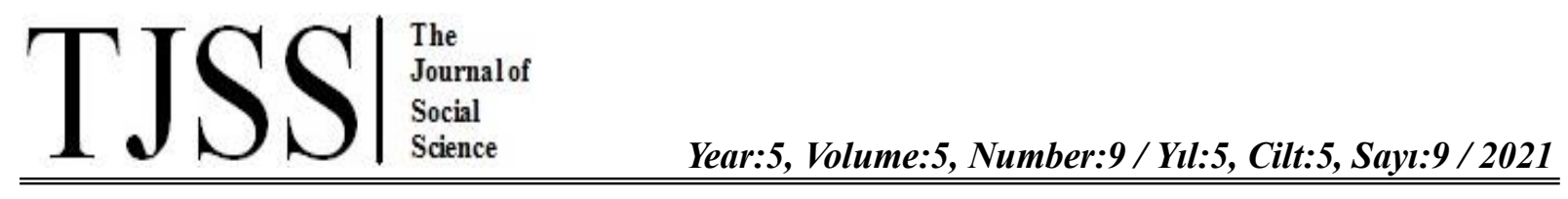

\section{Araștırma Alanın Kent Olma Süreci}

Eski bir yerleşim yeri olarak Batman'ın tarihi M.Ö. 546 y1lına dayanmakta ve zamanla Media, El Medine ve İluh adlarıyla anıldığı belirtilmektedir. Asıl adının nereden geldiği bilinmemekle beraber 1597 yılında Bitlis Beylerinden Şeref Han tarafindan yazılan "Şerefname" adlı eserde "Batman beyliklerinden" ve 17. yüzyılda Evliya Çelebi tarafindan yazılmış olan "Seyahatname" adlı eserde "Batman Nehri" ve "Batman Köprüsü'nden söz edilmektedir. Bugünkü Batman'ın bulunduğu yerleşim yeri, 1515 yılında Siirt vilayeti Elmedin kazasına bağlı İluh Köyü iken, 1926 yılında Elmedin kazasının sular altında kalması nedeniyle İluh Köyü, 1927 yılında Beşiri (Kobin) ilçesine bağlanmış ve 1937 yılında bucak olmuştur. 1935 yılında yapılan nüfus sayımında İluh'un nüfusu 319, 1940'ta 409, 1945'te 443, 1950'de 915 kişi olarak tespit edilmiştir (Bimay, 2019:128).

1950'li yılların başlarında bölgede bulunan petrol rezervlerinin değerlendirilmesi sonucunda sanayileşmeye bağlı artan içgöçlerle önemli bir kente dönüşmüştür. 1955'te yapılan genel nüfus sayımında Batman'ın nüfusu 4713 kişi olarak dünyada kısa süre içerisinde nüfusu katlanarak artan en önemli yerleşim yerlerinden biri olarak kaydedilmiştir. Artan nüfusa bağlı olarak 2 Kasım 1955'te "belediye”, 2 Eylül 1957 tarihinde "ilçe” teşkilatı kurulmuştur (Kaypak ve Bimay, 2016:95-97). Dolayısıyla kentleşme sürecinin başladığı ilk dönem, 1955'ten sonra petrol işinde çalışacak nitelikli işgücü göçünün yaşandığ 1 ve kentsel dönüşümün hissedildiği 1970'lara kadar devam etmiştir. Bu dönemde meydana gelen değişime bağlı gerçekleşen büyüme sanayi ile desteklenerek dengeli bir şekilde gerçekleşmiştir. Sanayileşmeye koşut yaşanan bu süreç, gelişmiş ülkelerde meydana gelen kentleşmeye benzer şekilde ortaya çıkmıştır. 1970'lerden sonra petrolün cazibesinin azaldığ 1 , nitelikli işgücü dışında kırdan kente göçün yaşandığı göç ve güvenlik ağırlıklı süreçte, mekânda dağılım süreci eşitsiz bir şekilde gerçekleştiği ortaya çıkmıştır. Sanayileşmeye paralel gelişemeyen kentte yaşanan hızlı ve yoğun nüfus artışının sonunda çarpık ve düzensiz kentleşme meydana gelmiş ve hızla büyüyen Batman, 1990 yılında Türkiye'nin 72. ili olmuştur. 1990'lardan sonra yaşanan çatışma ortamı ve bunun sonucunda meydana gelen çift yönlü (kırdan kente ve kentten kıra) göçler, Ilısu Barajı'nın yapılmasıyla birlikte Hasankeyf ve çevresinin içinde bulunduğu birçok yerleşim yerinin boşaltılması ve Suriye iç savaşı nedeniyle 2011 yılından sonra başlayan dış göçler kentin biçimlenmesinde, kent ve kentli kimliğinin oluşmasında önemli süreçler olarak kabul edilmektedir (Bimay, 2019:132-133).

\section{Yöntem}

$\mathrm{Bu}$ çalışmanın amacı, son yüzyılda hızlı kentleşen, gün geçtikçe sosyo-ekonomik ve demografik özellikler bakımından daha da büyüyen Batman'da, yerel halkın kentlileşmesinde veya kentli kimliğini elde etmelerinde kente duydukları aidiyet duygularını yerel katılım açısından incelemektir. Yapılacak saptamalar ve elde edilecek bulguların gelecekte kentlerle ilgili olarak oluşturulacak yerel politikalara yol göstermesi hedeflenmektedir. Araştırma için kullanılan yöntem, değişkenlerin ölçümlerinin rakamla ifade edilmesini sağlayan nicel araştırma yöntemidir (Punch, 2011). Bu bağlamda Batman'da yaşayan ve araştırmanın hedef evrenini oluşturan ana kütle içinden anket sorularını yanıtlamaya istekli 18 yaş üstü 238 kişi ile yüz yüze anket gerçekleştirilmiştir. Batman'ın nüfusu göz önüne alındığında bu oranın asgari düzeyde evreni temsil ettiğini belirtebiliriz. Araştırmanın kapsamı, kaynak yetersizliği ve COVID-19 pandemi sürecinin yüz yüze anket yapmak için getirdiği kısitlamalar nedeniyle sinırlı tutulmuştur. Anketler, Batman Üniversitesi Etik Kurulu'nun 13.07.2020 tarih ve E. 11592 sayılı onayıyla 2020 yılı ikinci yarısında gerçekleştirilmiştir. Anket yoluyla elde edilen bulguların betimsel veya tanımlayıcı istatistikleri, SPSS 24 programı kullanılarak frekans ve yüzde dağılımları şeklinde analiz edilmiş ve yorumlanmıştır. 


\subsection{Saha Çalışmasının Değerlendirilmesi}

$\mathrm{Bu}$ çalışmanın saha araştırması, Batman'da ikamet eden yerel halkın kentli kimliğini kazanmalarına etki eden unsurları yerel katılım olanakları açısından tespit etmek amacıyla yapılan anketlerden elde edilen bulguları içerir. Bulgular, verilenlerin yorumlanması, değerlendirilmesi ve öneriler sunulması şeklinde analiz edilmiştir.

\subsection{Bulgular}

$\mathrm{Bu}$ bölümde, Batman kentinde yapılan saha araştırmasından elde edilen verilerin yorumlanmasına ilişkin değerlendirmeler yer almaktadır.

\subsubsection{Demografik Özellikler Açısından}

Tablo 1. Katılımcıların Demografik Özelliklerine Göre Dağılımı (N=238)

\begin{tabular}{|c|c|c|}
\hline Katılımcıların Cinsiyeti & $\mathbf{F}$ & $\%$ \\
\hline Erkek & 114 & 47,9 \\
\hline Kadın & 124 & 52,1 \\
\hline Katılımcıların Yaş Grupları & $\mathbf{F}$ & $\%$ \\
\hline $18-28$ & 110 & 46,2 \\
\hline 29- 39 & 51 & 21,4 \\
\hline $40-50$ & 61 & 25,6 \\
\hline $51-61$ & 11 & 4,6 \\
\hline $62+$ & 5 & 2,1 \\
\hline Katılımcıların Eğitim Durumları & $\mathbf{F}$ & $\%$ \\
\hline Okuryazar değilim & 16 & 6,7 \\
\hline İlkokul/İlköğretim /Ortaokul Mezunu & 29 & 12,2 \\
\hline Lise mezunuyum & 67 & 28,2 \\
\hline Ön Lisans Mezunu & 31 & 13,0 \\
\hline Lisans Mezunu & 69 & 29,0 \\
\hline Lisansüstü mezunuyum & 26 & 10,9 \\
\hline Katılımcıların Meslekleri & $\mathbf{F}$ & $\%$ \\
\hline İş arayıp ta bulamayanlar & 17 & 7,1 \\
\hline Serbest meslekler(esnaf, avukat, muhasebeci, çiftçi vd.) & 17 & 7,1 \\
\hline Ev hanımı, öğrenci ve çalışmak istemeyenler & 110 & 46,2 \\
\hline Kamu Çalışanı & 80 & 33,6 \\
\hline Ücretli çalışan veya işçi & 14 & 5,9 \\
\hline Katılımcıların Geliri & $\mathbf{F}$ & $\%$ \\
\hline 1000 TL ye kadar & 70 & 29,4 \\
\hline $1000-2000$ TL aras1 & 38 & 16,0 \\
\hline $2001-3000$ TL aras1 & 26 & 10,9 \\
\hline 3 001- 4 000- TL aras1 & 11 & 4,6 \\
\hline $4001-5000$ TL aras1 & 38 & 16,0 \\
\hline 5001 TL ve üstü & 55 & 23,1 \\
\hline
\end{tabular}

Katılımcıların kentsel aidiyet duygusu yaşamasında ve kentli kimliği kazanmasında eğitim, gelir gibi demografik özelliklerin doğrudan etkisi bulunmaktadır. Yapılan bu araştırmanın örneklemini oluşturan kişilerin yarısından fazlası kadın katılımcılardan oluşmaktadır. Katılımcıların önemli çoğunluğu (\% 67,6) 18-40 yaş arası gençlerden oluştuğu ve çoğunun öğrenim düzeyi lise ve üniversite düzeyinde olduğu tespit edilmiştir. Kısmen de olsa okur-yazar 
olmayan katılımcılar da bulunmaktadır. Ayrıca katılımcıların içinde her meslekten insanların olduğu ve dolayısıyla gelir düzeyinin mesleklere göre farklılık gösterdiği de tablodan anlaşılmaktadır. Katılımcıların önemli bir bölümünün (\% 45,4) asgari ücretin altında gelir elde etmesi ve geri kalanların büyük bir bölümünün 4000 TL ve üzeri gelire sahip olması, gelir dağılımında adaletsizliğin olduğu da söylenebilir.

Tablo 2. Katılımcıların Beraber Yaşadığı Kişi Sayısına Göre Dağılımı (N=238)

\begin{tabular}{lll}
\hline Değişkenler & F & $\%$ \\
\hline 2 kişi & 14 & 5,9 \\
3 kişi & 16 & 6,7 \\
4 kişi & 39 & 16,4 \\
5 kişi & 46 & 19,3 \\
6 kişi ve üzeri & 123 & 51,7 \\
\hline
\end{tabular}

Tablo 2 incelendiğinde katılımcıların yaşadıkları evlerde beraber kaldıkları kişi sayısının fazla olduğu ve ailelerin genel olarak kalabalık ailelerden oluştuğu ortaya çıkmıştır. Buna göre katılımcıların yarısından fazlasının (\% 51,7) 6 kişiden fazla nüfusa sahip olduğu ve geri kalanların içinde 46'sı (\%19,3) 5 kişilik aile, 39'u (\%16,4) 4 kişilik, 30'u(\%12,6) ise 3 ve daha az nüfusa sahip ailede yaşadıkları ortaya çıkmıştır.

Tablo 3. Katılımcıların Batman'daki İkamet Sürelerine Göre Dağılımı (N=238)

\begin{tabular}{lll}
\hline Değişkenler & F & $\%$ \\
\hline 1 yıldan az & 31 & 13,0 \\
$1-6$ y1l & 27 & 11,3 \\
$7-10$ y1l & 11 & 4,6 \\
$11-20$ y1l & 47 & 19,7 \\
$21-30$ y1l & 56 & 23,5 \\
31 y1l ve üstü & 66 & 27,7 \\
\hline
\end{tabular}

Genellikle çocukluk ve gençlik yıllarının geçirildiği mekânlara karşı aidiyet hissinin daha yüksek olduğu bilinmektedir. Aynı şekilde yerelde yaşayan halkın kentlileşme düzeyi üzerinde kentte ikamet ettikleri yılların önemli bir etkisi bulunmaktadır. Bu anlamda katılımcıların çoğu (\% 75,7) 10 yıl ve üzeri bir sürede Batman'da ikamet ettikleri ve bu sürenin, katılımcıların kentleşme olanaklarından (eğitim, sağlık, ekonomik ve kültürel) daha iyi yararlanmaları için belirleyici bir unsur olduğu söylenebilir.

Tablo 4. Katılımcıların Geldikleri Yerleşim Yerine Göre Dağılımı (N=238)

\begin{tabular}{lll}
\hline Değişkenler & $\mathrm{F}$ & $\%$ \\
\hline Batman'a bağlı ilçe & 42 & 17,6 \\
Batman'a bağlı köyden/kasabadan & 52 & 21,8 \\
Başka bir il merkezinden & 40 & 16,8 \\
Başka bir ilçe merkezinden & 32 & 13,4 \\
Büyükşehir olan il merkezinden & 29 & 12,2 \\
Herhangi bir il veya ilçe merkezine bağlı köyden & 15 & 6,3 \\
Eskiden beri Batman merkezde ikamet edenler & 28 & 11,8 \\
\hline
\end{tabular}

İç ve dış göçler sonucunda ve sanayileşmenin getirdiği istihdam olanakları dışında gerçekleşen nüfus artışlarının neden olduğu kentleşme süreçlerinde, kentli kimliğinin oluşumu veya 
kentlileşme süreçlerinin gerçekleşmesi daha güç olmaktadır. Bunun nedeni kente göç ile gelen bireyin sosyo-ekonomik ve kültürel açıdan yaşayacağı uyum sorunlarından kaynaklanmaktadır. Batman kenti için yapılan bu çalışmada, katılımcıların büyük oranı $(\% 88,2)$ kente sonradan göç ettiği anlaşılmaktadır. Göç eden katılımcıların önemli oranı (\% 57,3) il ve ilçe merkezlerinden geldiği geri kalanı ise $(\% 23,9)$ kırsaldan göç ettiği ortaya çıkmıştır. Katılımcıların sadece 28'inin (\% 11,8) Batman' in eski yerlisi olduğu tablodan anlaşılmaktadır. Buradan hareketle Batman'a yerleşen kişilerin büyük çoğunluğunun il ve ilçelerden geldiği ve bunun uyumu kolaylaştırdığı söylenebilir.

Tablo 5. Katılımcıların Oturduğu Konut Tipine Göre Dağılımı (N=238)

\begin{tabular}{lll}
\hline Değişkenler & $\mathrm{F}$ & $\%$ \\
\hline Çok katlı bina & 141 & 59,2 \\
Bodrum katı & 3 & 1,3 \\
Çatı katı & 4 & 1,7 \\
Gecekondu & 7 & 2,9 \\
Müstakil bina & 40 & 16,8 \\
Müstakil tek katlı bina & 12 & 5,0 \\
Site içi müstakil konut & 11 & 4,6 \\
Diğer & 20 & 8,4 \\
\hline
\end{tabular}

Kentte yaşanan ekonomik koşullar ve katılımcıların oturdukları konutun niteliği kentli kimliğinin oluşmasında etkili olmaktadır. Batman, göçlerle büyüyen bir kent olmasına rağmen kentin dokusunu bozan gecekondu tarzında yerleşmelerin olmadığı söylenebilir. Genel olarak katılımcıların büyük çoğunluğu $(\% 85,6)$ çok katlı binalarda veya kendilerine ait müstakil evlerde oturdukları anlaşılmaktadır. Geri kalanların ise kötü koşullara sahip meskenlerde yaşadıkları ortaya çıkmıştır. 


\subsubsection{Yerel Katılım Açısından}

Tablo 6. Katılımcıların Yerel Katılıma İlişkin Düşüncelerine Göre Dağılımı(N=238)

\begin{tabular}{|c|c|c|c|c|c|c|c|}
\hline \multirow[b]{2}{*}{ İfadeler } & & \multicolumn{6}{|c|}{ Katılım Düzeyi } \\
\hline & & 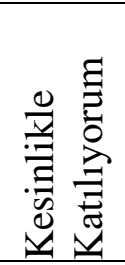 & 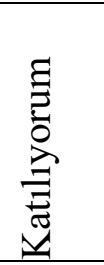 & 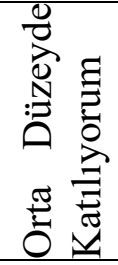 & 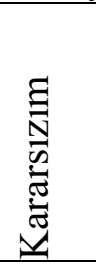 & 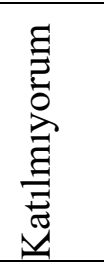 & 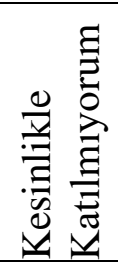 \\
\hline \multirow[t]{2}{*}{ Kent ile ilgili alınan kararlara katılırım. } & $\mathrm{F}$ & 20 & 55 & 55 & 42 & 41 & 25 \\
\hline & $\%$ & 8,4 & 23,1 & 23,1 & 17,6 & 17,2 & 10,5 \\
\hline \multirow{2}{*}{$\begin{array}{l}\text { Kentte alınan kararlara katılımımın } \\
\text { sağlanması kente olan aidiyet duygumu } \\
\text { artırmaktadır. }\end{array}$} & $\mathrm{F}$ & 49 & 108 & 23 & 28 & 17 & 13 \\
\hline & $\%$ & 20,6 & 45,4 & 9,7 & 11,8 & 7,1 & 5,5 \\
\hline \multirow{2}{*}{$\begin{array}{l}\text { Batman'da kent yönetimine katılım } \\
\text { konusunda gerekli yardım, bilgilendirme } \\
\text { olanakları sağlanmıştır. }\end{array}$} & $\mathrm{F}$ & 2 & 25 & 22 & 66 & 78 & 45 \\
\hline & $\%$ & 0,8 & 10,5 & 9,2 & 27,7 & 32,8 & 18,9 \\
\hline \multirow{2}{*}{$\begin{array}{l}\text { Batman belediyesi, imar, ulaşım gibi } \\
\text { önemli projelerde halkın görüşünü } \\
\text { sormaktadır. }\end{array}$} & $\mathrm{F}$ & 4 & 21 & 23 & 52 & 66 & 72 \\
\hline & $\%$ & 1,7 & 8,8 & 9,7 & 21,8 & 27,7 & 30,3 \\
\hline \multirow{2}{*}{$\begin{array}{l}\text { Batman'da kent konseyi etkin bir } \\
\text { biçimde çalışmaktadır. }\end{array}$} & $\mathrm{F}$ & 4 & 12 & 38 & 70 & 67 & 47 \\
\hline & $\%$ & 1,9 & 5,0 & 16,0 & 29,2 & 28,2 & 19,7 \\
\hline \multirow{2}{*}{$\begin{array}{l}\text { Mahallemizi temsil için kent konseyinde } \\
\text { çalışmaya davet edilirsem kabul ederim. }\end{array}$} & $\mathrm{F}$ & 20 & 57 & 28 & 63 & 47 & 23 \\
\hline & $\%$ & 8,4 & 23,9 & 11,8 & 26,5 & 19,7 & 9,7 \\
\hline \multirow{2}{*}{$\begin{array}{l}\text { Batman'da valilik, belediye ve sivil } \\
\text { toplum örgütleri uyum içinde çalışırlar. }\end{array}$} & $\mathrm{F}$ & 9 & 37 & 43 & 40 & 50 & 59 \\
\hline & $\%$ & 3,8 & 15,5 & 18,1 & 16,8 & 21,0 & 24,8 \\
\hline \multirow{2}{*}{$\begin{array}{l}\text { Batman'da hiç bir ayrım gözetilmeden } \\
\text { herkese "eşit" olarak hizmet } \\
\text { sunulmaktadır }\end{array}$} & $\mathrm{F}$ & 19 & 23 & 34 & 25 & 64 & 73 \\
\hline & $\%$ & 8,0 & 9,7 & 14,3 & 10,5 & 26,9 & 30,7 \\
\hline \multirow{2}{*}{$\begin{array}{l}\text { Batman'da bir derneğin veya vakfin } \\
\text { düzenlediği } \\
\text { katılabilirim. }\end{array}$} & $\mathrm{F}$ & 8 & 43 & 23 & 62 & 63 & 39 \\
\hline & $\%$ & 3,4 & 18,1 & 9,7 & 26,1 & 26,5 & 16,4 \\
\hline
\end{tabular}

Temel insani gereksinim olarak kabul edilen aidiyet duygusu, insanın kendisini bir sistemin vazgeçilmez ve tamamlayıcı parçası olarak görmesidir. Yerel yönetimlerin karar alma süreçlerinde vatandaşların karar alma süreçlerine dahil edilmesi katılımcı demokrasinin gelişmesinde ve vatandaşın kente olan aidiyet duygusunu arttırmada önemlidir. Ancak bu sürecin çoğu kez işletilmediği de ileri sürülmektedir. Bu bağlamda, katılımcıların yerel katılım açısından kentlileşme düzeylerini incelemek için kendilerine 6'l likert ölçekli sorular yöneltilmiştir. Katılımcıların çoğu (\% 75,7), kentsel aidiyet ve farkındalığın oluşabilmesi için yerel halkın yerel yönetimlerin kararlarına katılım sağlaması gerektiğini belirtmiştir. Bu çerçevede yerel yönetimin en önemli karar mekanizması olan Batman Belediyesi'nin imar, ulaşım vb. önemli kentsel yatırımlarda halkın görüşlerinin alınmadığını ve kent ile ilgili alınan kararlara katılım imkânlarının olmadığını katılımcıların yarısından fazlası $(\%$ 54,6) dile getirmiştir. Ayrıca kararsızlarla birlikte katılımcıların büyük çoğunluğu $(\% 79,4)$, yerel katılımın sağlanması için gerekli olanakların sağlanmadığını, kurumlar arasında yönetişimsel 
bir çalışma ortamının olmadığı, sunulan hizmetlerin halka eşit dağıtılmadığını, Kent Konseyinin çalışmalarının etkin olmadığını ve STK'ların faaliyetlerine rahat bir şekilde katılım sağlayamadıklarını belirtmiştir.

\subsubsection{Kent ve Kentli Kimliği, Kentsel Aidiyet ve Kentsel Farkındalık Düzeyi Açısından}

Tablo 7. Katılımcıların Batman'da Yaşadıkları En Önemli Sorunlar ve Onların Bu Sorunlara Maruz Kalma Derecelerine Göre Dağılımı (N=238)

\begin{tabular}{lllll}
\hline Değişkenler & \multicolumn{2}{c}{ Evet } & \multicolumn{2}{c}{ Hayır } \\
\hline Konut sorunu & F & $\%$ & F & $\%$ \\
Aşırı trafik & 164 & 68,9 & 74 & 31,1 \\
Can Güvenliği/Asayiş & 154 & 64,7 & 84 & 35,3 \\
Çevre kirliliği & 102 & 42,9 & 136 & 57,1 \\
Gürültü kirliliği & 199 & 83,6 & 39 & 16,4 \\
Hayat pahalılığı & 171 & 71,8 & 67 & 28,2 \\
Kalabalık nüfus & 160 & 67,2 & 78 & 32,8 \\
Altyapi (Yol, su, elektrik, kanalizasyon) hizmetlerinin & 94 & 39,5 & 144 & 60,5 \\
Ulaşım sorunu & 180 & 75,6 & 58 & 24,4 \\
Otopark yetersizliği & 131 & 55,0 & 107 & 45,0 \\
Yeşil alan yetersizliği & 177 & 74,4 & 61 & 25,6 \\
Çarpık ve Plansız yapılaşmanın olması & 207 & 87,0 & 31 & 13,0 \\
Sağlik hizmetlerinin yetersizliği & 187 & 78,6 & 51 & 21,4 \\
Belediye hizmetlerinin pahalı olması & 156 & 65,5 & 82 & 34,5 \\
\hline
\end{tabular}

Katılımcıların yaşadığı kentteki sorunlara karşı olan duyarlılığı aidiyet, farkındalık ve katılım açısından kentli kimliği kazanmalarında önemli rol oynamaktadır. Tablo 5'te kentte yaşanan her sorun için katılımcıların bu sorunu yaşayıp yaşamadığı sorulmuştur. Buna göre katılımcıların büyük çoğunluğu (\% 87) kentteki yeşil alanların (park, bahçe ve mesire alanları) yetersiz olmasından şikâyetçi oldukları anlaşılmaktadır. Bunun dışında çevre kirliliği, çarpık ve plansız yapılar, altyapı sorunları, otopark yetersizliği, gürültü kirliliği, konut sorunu ve hayat pahalılığı katılımcıların en çok karşılaştığ 1 sorunlar olarak ortaya çıkmıştır. Dolayısıyla bireyin kentsel aidiyet ve kentli kimliğini elde etmesi için kentleşme sürecindeki çevresel, siyasal ve ekonomik tüm kentsel haklardan yararlanması zorunlu bir unsur olarak karşımıza çıkmaktadır. 
Tablo 8. Kentli Olma Unsurları ve Katılımcıların Bu Unsurları Önemsemelerine Göre Dağılımı $(\mathrm{N}=238)$

\begin{tabular}{lllll}
\hline Değişkenler & \multicolumn{2}{c}{ Evet } & \multicolumn{2}{c}{ Hayır } \\
\hline Çocuk sayısının az olması & F & $\%$ & F & $\%$ \\
Çok katlı dairelerde oturulması & 69 & 29,0 & 169 & 71,0 \\
Modern kılık kıyafet giyilmesi & 96 & 40,3 & 142 & 59,7 \\
Nezaket kurallarına dikkat edilmesi & 96 & 40,3 & 142 & 59,7 \\
Gelir düzeyinin yüksek olması & 155 & 65,1 & 83 & 34,9 \\
Saygılı ve nazik olunması & 94 & 39,5 & 144 & 60,5 \\
Kibirli olma & 149 & 62,6 & 89 & 37,4 \\
Zenginlik & 58 & 24,4 & 180 & 75,6 \\
Eğitimli ve kültürlü olmak & 70 & 29,4 & 168 & 70,6 \\
Önemli mevkilerde olmak & 177 & 74,4 & 61 & 25,6 \\
Kentte yaşamak & 88 & 37,0 & 150 & 63,0 \\
Hizmet sektöründe çalışmak & 175 & 73,5 & 63 & 26,5 \\
\hline
\end{tabular}

Kentlileşme sürecinde bireyin yaşamında yaşanan değişim ve dönüşümlere bağlı olarak birçok kentsel davranış ortaya çıkmaktadır. Tablo 8'de sayılan bu davranışların kentli kimliğinin oluşumunda etkili olup olmadığ1 ve kentli kimliğine sahip olmak için kişilerin hangi tür davranış ve özellikleri bulundurması gerektiği konusunda katılımcılara sorular yöneltilmiştir. Katılımcıların çoğu kentte yaşayan eğitimli, kültürel değerleri benimseyen, nezaket ve hoşgörü kurallarını yaşamayı ve bu kurallara uygun davranmayı ilke edinen kişilerin kentli kimliğine sahip olacaklarını ifade etmişlerdir. Dolayısıyla kentte yaşayanların kentli olma bilincine sahip oldukları ve kentsel hakların da farkında oldukları anlaşılmaktadır.

Tablo 9. Katılımcıların Batmanda Bulunan ve Kentin En Önemli Kültürel Değerleri Olan Kurum ve Mekânları Ziyaret Edip Etmediklerin Göre Dağılımı (N=238)

\begin{tabular}{lllll}
\hline Değişkenler & \multicolumn{2}{c}{ Evet } & \multicolumn{2}{c}{ Hayır } \\
\hline & F & $\%$ & F & $\%$ \\
\hline Hiç Batman Petrolspor maçına gittiniz mi? & 71 & 29,8 & 167 & 70,2 \\
Hiç Batman Müzesini gezdiniz mi? & 96 & 40,3 & 142 & 59,7 \\
Hiç TPAO Tesislerine gittiniz mi? & 177 & 74,4 & 61 & 25,6 \\
Hiç Batman Üniversitesine gittiniz mi? & 188 & 79,0 & 50 & 21,0 \\
\hline
\end{tabular}

Kentsel aidiyet ve farkındalığın oluşmasında etkili olan en önemli unsurlardan biri kente sahip çıkan, kentin varlığıyla özdeşleşen ve sosyo-ekonomik ve kültürel yaşamı düzenleyen kurumların varlığıdır. Tablo 10'da katılımcılara Batman'ın en önemli sosyo-ekonomik ve kültürel kurumları ve mekânları ziyaret edip etmediklerine ilişkin yöneltilen soruya genel olarak katılımcıların büyük bir bölümü olumlu yaklaşım sergilemiştir. Kentsel aidiyet ve farkındalık duygusunu arttıran bu türden yerler arasında sosyo-ekonomik katma değeri en yüksek olan TPAO tesisleri gelmektedir. Katılımciların 177'si $(\% 74,4)$ TPAO tesislerini ziyaret ettiğini, 61'i $(\% 25,6)$ ise tesisler hakkında bilgi sahibi olmadığını belirtmiştir. Yine katılımcıların önemli oranı (\% 79,0) Batman Üniversitesi'ne gittiğini, 50'sı (\% 21,0) ise hiç gitmediğini belirtmiştir. Batman Müzesine ve Batman Petrolspor maçlarına gidenlerinde ortalamanın altında olduğu söylenebilir. 
Tablo 10. Katılımcıların Kent ve Kentli Kimliği, Kentsel Aidiyet ve Kentsel Farkındalık düzeylerine Göre Dağılımı(N=238)

\begin{tabular}{|c|c|c|c|c|c|c|c|}
\hline \multirow[b]{2}{*}{ İfadeler } & & \multicolumn{6}{|c|}{ Katılım Düzeyi } \\
\hline & & 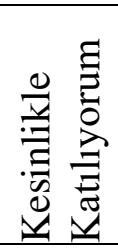 & 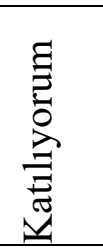 & 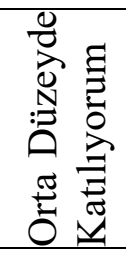 & 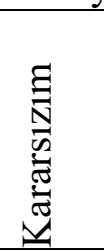 & 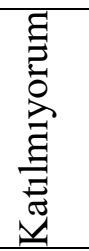 & 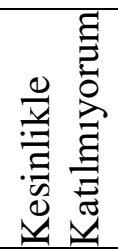 \\
\hline \multirow{2}{*}{$\begin{array}{l}\text { Çocuklarımın geleceğini Batman'da } \\
\text { kurmasını isterim. }\end{array}$} & $\mathrm{F}$ & 14 & 36 & 25 & 56 & 48 & 59 \\
\hline & $\%$ & 5,9 & 15,1 & 10,5 & 23,5 & 20,2 & 24,8 \\
\hline \multirow{2}{*}{$\begin{array}{l}\text { Batman'da doğmasa bile kendini buralı } \\
\text { hisseden herkes Batmanlıdır }\end{array}$} & $\mathrm{F}$ & 52 & 89 & 24 & 20 & 25 & 28 \\
\hline & $\%$ & 21,8 & 37,4 & 10,1 & 8,4 & 10,5 & 11,8 \\
\hline \multirow{2}{*}{$\begin{array}{l}\text { Kendimi yaşadığım kentin bir parçası } \\
\text { olarak görüyorum }\end{array}$} & $\mathrm{F}$ & 57 & 88 & 38 & 15 & 18 & 22 \\
\hline & $\%$ & 23,9 & 37,0 & 16,0 & 6,3 & 7,6 & 9,2 \\
\hline \multirow{2}{*}{$\begin{array}{l}\text { Batman'da insanlar } \\
\text { hoşgörülüdür. }\end{array}$} & $\mathrm{F}$ & 15 & 57 & 71 & 25 & 46 & 24 \\
\hline & $\%$ & 6,3 & 23,9 & 29,8 & 10,5 & 19,3 & 10,1 \\
\hline \multirow{2}{*}{$\begin{array}{l}\text { Ailemden birinin farklı bir siyasal partiye } \\
\text { oy vermesini hoş karşılarım. }\end{array}$} & $\mathrm{F}$ & 79 & 86 & 25 & 22 & 18 & 8 \\
\hline & $\%$ & 33,2 & 36,1 & 10,5 & 9,2 & 7,6 & 3,4 \\
\hline \multirow{2}{*}{$\begin{array}{l}\text { Apartmanlarda ayakkabıların kapı önüne } \\
\text { bırakılmasını yadırgıyorum }\end{array}$} & $\mathrm{F}$ & 27 & 48 & 39 & 29 & 57 & 38 \\
\hline & $\%$ & 11,3 & 20,2 & 16,4 & 12,2 & 23,9 & 16,0 \\
\hline \multirow{2}{*}{$\begin{array}{l}\text { Ramazan'da, hasta olanların dışında oruç } \\
\text { tutmayanlara hoşgörüyle bakıyorum }\end{array}$} & $\mathrm{F}$ & 79 & 83 & 28 & 8 & 24 & 16 \\
\hline & $\%$ & 33,2 & 34,9 & 11,8 & 3,4 & 10,1 & 6,7 \\
\hline \multirow{2}{*}{$\begin{array}{l}\text { Düğün, maç gibi özel günlerde korna } \\
\text { çalanları hoş görmüyorum }\end{array}$} & $\mathrm{F}$ & 73 & 48 & 30 & 18 & 41 & 28 \\
\hline & $\%$ & 30,7 & 20,2 & 12,6 & 7,6 & 17,2 & 11,8 \\
\hline \multirow{2}{*}{$\begin{array}{l}\text { Parkta gördüğüm bir ambalaj atığını, bana } \\
\text { ait olmasa da alıp çöpe atarım }\end{array}$} & $\mathrm{F}$ & 69 & 94 & 39 & 12 & 15 & 9 \\
\hline & $\%$ & 29,0 & 39,5 & 16,4 & 5,0 & 6,3 & 3,8 \\
\hline \multirow{2}{*}{$\begin{array}{l}\text { Kentle ilgili güncel gelişmeleri yerel } \\
\text { gazete veya internetten takip ederim }\end{array}$} & $\mathrm{F}$ & 54 & 101 & 35 & 10 & 23 & 15 \\
\hline & $\%$ & 22,7 & 42,4 & 14,7 & 4,2 & 9,7 & 6,3 \\
\hline \multirow{2}{*}{$\begin{array}{l}\text { Batmanlı iş adamları ve sanatçıları takip } \\
\text { ederim }\end{array}$} & $\mathrm{F}$ & 14 & 52 & 43 & 21 & 64 & 44 \\
\hline & $\%$ & 5,9 & 21,8 & 18,1 & 8,8 & 26,9 & 18,5 \\
\hline \multirow{2}{*}{$\begin{array}{l}\text { Komşu ve arkadaşlarımın cenaze, düğün } \\
\text { veya nişan törenlerine katılırım. }\end{array}$} & $\mathrm{F}$ & 60 & 114 & 35 & 14 & 8 & 7 \\
\hline & $\%$ & 25,2 & 47,9 & 14,7 & 5,9 & 3,4 & 2,9 \\
\hline
\end{tabular}

Katılımcıların kent ve kentli kimliğinin oluşmasında etkili olan kentsel aidiyet ve farkındalık ile ilgili görüşlerine bakıldığında, Katılımcıların çoğu (\% 79,8) kent ile ilgili gelişmeleri basılı veya online yayınlanan yerel gazetelerden takip ettiklerini, 183 'ü $(\% 76,9)$ kendilerini kentin bir parçası olarak gördüklerini, ancak buna rağmen geleceklerini Batman'da kurmak isteyen katılımcı oranının düşük (\% 31,5) olduğu tespit edilmiştir. Ayrıca katılımcıların 190’1 $(\% 79,9)$ siyasi farklılıkları hoş karşıladıklarını, 143'ü (\% 60) Batmanlıların nazik ve hoş görülü olduklarını, 190'ı (\%79,9) dinsel hoşgörüden yana olduklarını, 202'si (\% 84,9) çevresel duyarlığa sahip olduğunu, 151'i $(\%$ 63,7) korna çalma gibi gürültü kirliliğine neden olan davranışları benimsemediklerini, 209'u (\% 87,8) gelenek ve göreneklerine riayet ettiklerini, 
109 ’u $(\% 45,8)$ ise kentin ünlü simalarını takip ettiğini belirtmiştir. Dolayısıyla katılımcıların kent ve kentli kimliğinin oluşmasına katkı sunan tüm unsurların bilincinde oldukları anlaşılmaktadır.

\subsubsection{Kentsel Hakların Kullanımı Açısından}

Tablo 11. Katılımcıların Kentsel Hakları Kullanıp Kullanmamasına Göre Dağılımı (N=238)

\begin{tabular}{lcccc}
\hline Değişkenler & Evet & \multicolumn{3}{c}{ Hayır } \\
\hline Ulaşım / Dolaşım Hakk1 & F & $\%$ & F & $\%$ \\
Sağlık Hakk1 & 199 & 83,6 & 39 & 16,4 \\
Konut / Barınma Hakk1 & 170 & 71,4 & 69 & 28,6 \\
Güvenlik Hakk1 & 163 & 68,5 & 75 & 31,5 \\
Çalışma / İstihdam Hakkı & 162 & 68,1 & 76 & 32,0 \\
Sağlıklı bir çevrede yaşama hakk1 & 135 & 56,7 & 103 & 43,2 \\
Katılım Hakkı & 106 & 44,5 & 132 & 55,5 \\
Spor ve Dinlence Hakk1 & 122 & 51,3 & 116 & 48,8 \\
& 129 & 54,2 & 109 & 45,8 \\
\hline
\end{tabular}

Kentlileşme ve kentli kimliğine sahip olmanın en önemli koşullardan biride kentsel hakların kullanımının eksiksiz gerçekleşebilmesidir. 1970'lerden itibaren ikinci ve üçüncü kuşak haklar kapsamında değerlendirilen bu hakların çoğu, son otuz yıl içinde BM ve AB gibi uluslararası aktörlerin baskı ve zorlamasıyla ülkelerin mevzuatında yer almış ve uygulamaları kısmen bu çerçevede gerçekleşmiştir. Tablo 9'a bakıldığında katılımcıların büyük çoğunluğu $(\% 83,6)$ Batman'da kullanılabilen en iyi kentsel haklar olarak ulaşım veya dolaşım hakkını, en az kullanılanları ise yerel katılım ve sağlıklı bir çevrede yaşama haklarını belirtmişlerdir. Dolayısıyla kentli olma, kentsel değerlere sahip olma ve onları korumada en önemli hakların başında gelen katılım hakkı, kullanım imkânları açısından en alt kategoride değerlendirilmesi, kentli kimliği elde etme konusunda olumsuz bir durum olarak karşımıza çıkmaktadır. 
Tablo 13. Katılımcıların Kullandıkları Kentsel Hakların Kullanımına İlişkin Düşüncelerine Göre Dağılımı

\begin{tabular}{|c|c|c|c|c|c|c|c|}
\hline \multirow[b]{2}{*}{ İfadeler } & & \multicolumn{6}{|c|}{ Katılım Düzeyi } \\
\hline & & 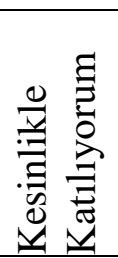 & 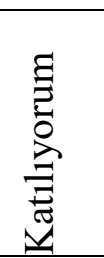 & 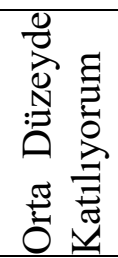 & 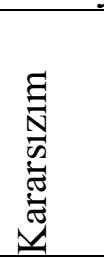 & 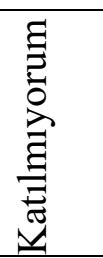 & 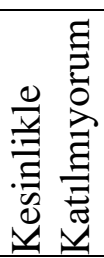 \\
\hline \multirow{2}{*}{$\begin{array}{l}\text { Yaşadığım yerin doğal çevresine zarar } \\
\text { verildiğginde buna karşı çıkarım }\end{array}$} & $\mathrm{F}$ & 87 & 112 & 17 & 11 & 5 & 6 \\
\hline & $\%$ & 36,6 & 47,1 & 7,1 & 4,6 & 2,1 & 2,5 \\
\hline \multirow{2}{*}{$\begin{array}{l}\text { Batman Belediyesi'nin temizlik hizmetleri } \\
\text { memnuniyet vericidir }\end{array}$} & $\mathrm{F}$ & 19 & 64 & 53 & 37 & 41 & 24 \\
\hline & $\%$ & 8,0 & 26,9 & 22,3 & 15,5 & 17,2 & 10,1 \\
\hline \multirow{2}{*}{$\begin{array}{l}\text { Batman'da doğal zenginlikler ve kaynaklar } \\
\text { Belediye tarafindan yaşayanların yararı } \\
\text { gözetilerek korunmaktadır }\end{array}$} & $\mathrm{F}$ & 2 & 22 & 49 & 47 & 64 & 54 \\
\hline & $\%$ & ,8 & 9,2 & 20,6 & 19,7 & 26,9 & 22,7 \\
\hline \multirow{2}{*}{$\begin{array}{l}\text { Batman'da kent sakinlerinin beden ve ruh } \\
\text { sağlığının korunmasına yardımcı çevre } \\
\text { kosulları vardır }\end{array}$} & $\mathrm{F}$ & 2 & 20 & 43 & 43 & 79 & 51 \\
\hline & $\%$ & 0,8 & 8,4 & 18,1 & 18,1 & 33,2 & 21,4 \\
\hline \multirow{2}{*}{$\begin{array}{l}\text { Batman kent sakinlerinin boş vakitlerini } \\
\text { değerlendirebileceği yeterli spor ve mesire } \\
\text { olanakları vardır }\end{array}$} & $\mathrm{F}$ & 3 & 17 & 30 & 36 & 65 & 87 \\
\hline & $\%$ & 1,3 & 7,1 & 12,6 & 15,1 & 27,3 & 36,6 \\
\hline \multirow{2}{*}{$\begin{array}{l}\text { Belediye hizmet aracının kanunlara aykırı } \\
\text { kullanıldığını görsem belediyeye bildiririm }\end{array}$} & $\mathrm{F}$ & 43 & 76 & 42 & 32 & 36 & 9 \\
\hline & $\%$ & 18,1 & 31,9 & 17,6 & 13,4 & 15,1 & 3,8 \\
\hline \multirow{2}{*}{$\begin{array}{l}\text { Kaza, yangin veya güvenlik problemi } \\
\text { olduğunda müdahale ederim veya yetkililere } \\
\text { haber veririm }\end{array}$} & $\mathrm{F}$ & 79 & 113 & 20 & 7 & 8 & 11 \\
\hline & $\%$ & 33,2 & 47,5 & 8,4 & 2,9 & 3,4 & 4,6 \\
\hline \multirow{2}{*}{$\begin{array}{l}\text { Batman'da davranışlarımı kısıtlayan bir } \\
\text { ortam yoktur }\end{array}$} & $\mathrm{F}$ & 15 & 62 & 35 & 28 & 44 & 54 \\
\hline & $\%$ & 6,3 & 26,1 & 14,7 & 11,8 & 18,5 & 22,7 \\
\hline \multirow{2}{*}{$\begin{array}{l}\text { Batman'da sosyal ve kültürel faaliyetler } \\
\text { yeterli düzeydedir }\end{array}$} & $\mathrm{F}$ & 2 & 26 & 19 & 28 & 80 & 83 \\
\hline & $\%$ &, 8 & 10,9 & 8,0 & 11,8 & 33,6 & 34,9 \\
\hline \multirow{2}{*}{$\begin{array}{l}\text { Batman'da yapılan binalar imara uygun } \\
\text { yapılmaktadır }\end{array}$} & $\mathrm{F}$ & 2 & 10 & 37 & 44 & 83 & 62 \\
\hline & $\%$ &, 8 & 4,2 & 15,5 & 18,5 & 34,9 & 26,1 \\
\hline \multirow{2}{*}{$\begin{array}{l}\text { Batman'da kaldırımlar, engellilerin } \\
\text { kullanımına uygundur. }\end{array}$} & $\mathrm{F}$ & 4 & 30 & 41 & 34 & 63 & 66 \\
\hline & $\%$ & 1,7 & 12,6 & 17,2 & 14,3 & 26,5 & 27,7 \\
\hline \multirow{2}{*}{$\begin{array}{l}\text { Batman'da tüm yol kullanıcılarının (yaya, } \\
\text { araç ve bisiklet vb. kullanan) birbirlerini } \\
\text { kısıtlamaksızın düzenli bir işleyişi vardır }\end{array}$} & $\mathrm{F}$ & 7 & 21 & 35 & 36 & 75 & 64 \\
\hline & $\%$ & 2,9 & 8,8 & 14,7 & 15,1 & 31,5 & 26,9 \\
\hline
\end{tabular}

Katılımcıların, yerel katılım açısından kentsel aidiyet duygusu ve yerel farkındalığı oluşturabilmeleri için kente özgü sayılan ve kentleşme süreci ile ortaya çıkan kentli haklarının sorunsuz bir şekilde kullanabilmesi gerekmektedir. Bunun için bireylerin, kentli olduklarının bilincinde olmaları, kente özgü tutum ve davranışları benimseyip içselleştirmeleri ve bunları uygulamaları gerektiğinin farkında olmalarıdır. Tablo 11'de katılımcıların özellikle çevre konusunda duyarlı oldukları ve çevreye verilen zararların önlenmesine yönelik verilecek mücadeleyi önemsedikleri görülmektedir. Katılımcıları tamamına yakını $(\% 90,8)$ kentin doğal 
yapısına zarar verildiğinde, yangın veya güvenlik problemi olduğunda veya kamu mallarının kanunlara aykırı kullanıldığını tespit ettiklerinde müdahale edeceklerini veya yetkililere haber vereceklerini belirtmişlerdir. Ancak katılımcıların yarısından fazlası (\% 53) bu hakları koruma konusunda kendilerini kısıtlayan veya engelleyen durumların olduğunu ifade etmişlerdir. Ayrıca Batman'da kent sakinlerinin beden ve ruh sağlı̆̆ının korunmasına yardımcı çevre koşullarının ve hatta yeterli spor ve mesire alanlarının bulunmadığını katılımcıların çoğu (\% 63,9) ifade etmektedir. Benzer şekilde kentleşme altyapısı açısından dezavantajlı grupların kullanımına uygun kaldırım ve yolların olmadığı, sosyal ve kültürel faaliyetlerin yetersiz olduğu ve çarpık kentleşmenin devam ettiği belirtilmişstir.

\section{Sonuç ve Öneriler}

Kentler, ortaya çıktığı günden itibaren iç ve dış koşullara göre biçimlenmekte ve işlevselliğini sürekli arttırmaktadır. Günümüzde kentler, küreselleşme ve toplumsal değişime bağlı olarak salt niceliksel bir büyüme sağlamamakta, aynı zamanda bilgi birikimine dayalı olarak kentte yaşayanların refahını ve huzurunu sağlayan ve kentsel haklar bağlamında bilinç ve aidiyet duygusu oluşturan mekânlar olarak karşımıza çıkmaktadır. Bu anlamda kentte yaşayanların kentin vizyonuyla örtüşen bir misyonu üstlenmesi anlamında yerel halkın kente olan bağlılığını sağlamak, kent ve kentli kimliğinin oluşmasına katkı sunmak için sosyo-ekonomik, kültürel ve siyasal yaşamı düzenleyen çevresel ve katılım mekanizmalarını hayata geçirmek ve kentsel sorunları bu düzlemde çözmek gerekir. Bugün birçok ölçekte yapılan araştırmalar göstermektedir ki kentlerin nüfus ve alan açısından büyümesi ve genişlemesi onları kentlileştirmez. Aksine bu büyüme ve genişleme, yığınların mekânları hor kullandığı sağlıksız bir çevreyi meydana getirmekte ve gelecek nesillerinde hayatını riske atmaktadır. Bu çerçevede ele alınan çalışmamızda, yerel katılım açısından kentsel bilinç ve aidiyet düzeyine ilişkin Batman kenti ile ilgili ortaya çıkan sonuçlar şu şekilde özetlenebilir:

- Yerel katılım mekanizmaları açısından kentsel aidiyet duygularının incelenmesine yönelik yapılan bu araştırmada, başta eğitim düzeyi, gelir, oturduğu konut, beraber yaşadığı kişi sayısı, ikamet süresi, sosyal ve kültürel değerler, kentsel haklar, kentsel sorunlara bakış açısı olmak üzere kentlilerin demografik ve çevresel özellikleri katılımcıların kentsel aidiyet duyguları üzerinde etkili olduğu söylenebilir. Yapılan araştırmaya katılan katılımcıların çoğunun on yıldan daha fazla Batman'da ikamet ettikleri, çocukluk ve gençliklerini burada geçirdikleri, eğitim seviyelerinin yüksek olduğu, beraber yaşanılan kişi sayısının fazla olduğu ve gelirdeki adaletsizliğin yüksek olduğu ortaya çıkmıştır.

- Kentte yaşayanların kentine sahip olma konusunda bilinçli olduğu,kentsel davranışları içselleştirdikleri ve kentine sahip çıkmak için uğraş verdikleri ortaya çıkmıştır. Ayrıca katılımcıların çoğu, kentte yaşayan eğitimli, kültürel değerleri benimseyen, nezaket ve hoşgörü kurallarını yaşamayı ve bu kurallara uygun davranmayı ilke edinen kişilerin kentli kimliğine sahip olacaklarını ifade etmişlerdir. Ancak kentsel hakların kullanımı açısından gerekli ortamın sağlanamadığı, bu hakları talep etme noktasında kendilerini kısıtlayan koşulların var olduğu belirtilmiş ve bu nedenle kentsel haklar açısından katılım haklarının kullanım düzeyinin en alt sıralarda olduğu tespit edilmiştir.

- Katılımcılar, ayrıca yerel yönetimlerin kent ile ilgili çalışmalarında yerel halkın görüşünü önemsemediği, yerel hizmetlerin halka eşit ve adil dağıtılmadığı, yerel halkın en önemli katılım mekanizması olan kent konseyinin etkin olamadığı ve STK'ların faaliyetlerine 
özgür bir şekilde katılım sağlanamadığını ifade etmişlerdir. Dolayısıyla bu durum, kentlilerin kentli kimliğine sahip olmasını ve kentsel aidiyet duygusu elde etmelerini de engellemektedir.

- Diğer taraftan katılımcıların beden ve ruh sağlığının korunmasına yardımcı çevre koşullarının olmadığ yönelik çarpık ve düzensiz imar yapılarının devam ettiği tespit edilmiştir.

$\mathrm{Bu}$ çalışmanın bulguları dikkate alındığında, her geçen gün büyüyen ve genişleyen kentlerde, kent ve kentli kimliğini oluşturabilecek kurum ve kuruluşların yerel halkın katılımına açık bir şekilde işlevselliğini sürdürmesi ve yerel halkın tüm kentsel haklarını kullanabileceği ortamların oluşturulması gerektiğini bize göstermektedir. Bilgi çağında yaşadığımız bu dönemde, Batman'daki yerel halkın kentsel haklarının farkında olmalarına ve etkin bir kentli kimliğini içselleştirmeye çalışmalarına rağmen hala kentsel aidiyet duygularının gelişmediği tespit edilmiştir. Bunun en önemli nedeni, kentsel hakların kullanımında karşılaşılan sorunlardır. Batman'da yerel düzeyde demokrasinin sağlanabilmesi, kentsel yaşam kalitesinin yükseltilmesi, sürdürülebilir kentleşme ve toplumsal uyum dengesi için halkın bilgisinin önemsenmesi, karar alma süreçlerine katılımının sağlanması ve sağlıklı bir çevre dahil tüm kentsel hakları hiçbir engelle karşılaşmadan gerçekleştirebilmesi gerekir. Ayrıca Batman'da yaşam kalitesinin arttırılması için kentte yaşayanlara yönelik sosyo-kültürel yatırımların hayata geçirilmesi, kentli olma duygusunu oluşturmada ve yerel katılımı sağlamada etkili olacaktır. Diğer taraftan kentin özellikle dezavantajlı grupları olan çocuk, kadın ve yaşlılar için farklı katılım mekanizmalarının geliştirilmesi ve bu gruplarla ilgili yapılacak tüm yatırımlarda bu grupların önerilerinin dikkate alınarak hareket edilmesi, yerel katılımın en önemli mekanizmalarından olan ve toplumsal sorunları çözmek için öneri geliştiren STK'ların faaliyetlerine katılma konusunda da tüm engellerin kaldırılması yerel katılıma önemli katkı sağlayacaktır. Kent ve kentli kimliğini oluşturmada belirleyici olan belediyelerin başta çevre hizmetlerinde olmak üzere yerelde sunulacak tüm hizmetlerde katılımın sağlanabilmesi için başarıyı özendiren, ödüllendiren ve değerlendiren uygulamalarla aktif rol almalarının sağlanması için daha etkin olmalarının sağlanması ve bu doğrultuda politika oluşturulması gerekmektedir. Böylece yerel katılım mekanizmaları devreye sokularak kentlilerin kentsel haklarını daha iyi kullanmalarının sağlanması, hem kente sahip çıkılmasında ve kentsel aidiyet duygularının arttırılmasında önemli bir işlev görecek, hem de kent ve kentli kimliğini oluşturacaktır.

\section{Kaynakça}

Apan A. (2016). Bütünşehir Modeli ve Taşra Yönetimine Etkileri. Çağdaş Yerel Yönetimler, 25(1), 1-24.

Aslanoğlu, R. (2000). Kent, Kimlik ve Küreselleşme. Bursa: Asa Kitabevi.

Batmaz, N. Y. \& Gürer, A. (2016). Kırıkkale İlinin Kentlilik Bilinci Bağlamında Değerlendirilmesi Üzerine Bir Araştırma, 4. Uluslararası Kentsel ve Çevresel Sorunlar ve Politikalar Kongresi Bildirileri, 163-177.

Bauman, Z. (2000). Siyaset Arayışı. Tuncay Birkan (Çev.), İstanbul: Metis Yayınları. 
Beyazıt, E., Gül, H. \& Güneş, M. (2013). Kent Kimliği ve Kimliksizleş (tiril)en Kentler Üzerine Bir Tartışma. Cem Ergun, Muharrem Güneş ve Ayşe Dericioğulları Ergun(Ed.), Kent Üzerine Özgür Yazılar (ss. 149-162), İstanbul: Bağlam Yayıncılık,

Bimay, M. (2019). Göçün Kentleşme Üzerindeki Sosyo-Ekonomik ve Kültürel Etkileri: Batman Örneği. Yayımlanmamış Doktora Tezi. Hatay: Hatay Mustafa Kemal Üniversitesi. Sosyal Bilimler Enstitüsü.

Bimay, M. (2020). Mardin Büyükşsehir Belediyesi Örneğinde Yeni Büyükşehir Belediye Modeli Uygulamasının Yerel Halka Yansımaları. OPUS Uluslararası Toplum Araştırmaları Dergisi, Eğitim ve Toplum Özel sayıs1, 6215-6243 . DOI: 10.26466/opus.823674.

Bozloğan, R. (2005). Sürdürülebilir Gelişme Düşüncesinin Tarihsel Arka Planı. İstanbul Üniversitesi Sosyal Siyasal Konferanslar Dergisi, 50, 1011-1028.

Bulut Y. \& Bimay M. (2019). Belediye Meclislerinde Temsil ve Katılım: Batman, Mardin, Adıyaman Örneği. Çăgdaş Yerel Yönetimler Dergisi, 28(4), 49-64.

Castells, M. (2006). Enformasyon Çağg: Ekonomi, Toplum ve Kültür. 2. Cilt: Kimliğin Gücü. Ebru Kılıç(Çev.), İstanbul: İstanbul Bilgi Üniversitesi Yayınları.

Castells, M. (2014). Kent, Sınıf, İktidar. Asuman Türkün(Çev.), Ankara: Phoenix Yayınları.

Childe, G. (2006). Kendini Yaratan İnsan: İnsanın Çă̆lar Boyu Gelişimi. Filiz Ofluoğlu(Çev.), İstanbul: Varlık Yayınları.

Çınar, T., Çiner, C., U. \& Zengin, O. (2009). Büyükşehir Yönetimi Bütünleştirme Süreci. 1. Baskı, Ankara: Türkiye ve Ortadoğu Amme İdaresi Enstitüsü Yayınları.

Eke, A.E. (1982). Anakent Yönetimi ve Yönetimlerarası İlişkiler. Ankara: Ankara Üniversitesi Siyasal Fakültesi Yayınları, No.5.

Erkut, G. (1991). Kentleşme Sürecinin Sosyolojik Boyutu. Hande Süher (Ed.), Kentleşme ve Kentlileşme Politikaları (ss.37-67), İstanbul: TÜSES Yayınları.

Es, M. \& Ateş, H. (2004). Kent Yönetimi, Kentlileşme ve Göç: Sorunlar ve Çözüm Önerileri. Sosyal Siyaset Konferanslarl Dergisi, 48, 205-248.

Frey, W. H. \& Zimmer, Z. (2001). Defining the City. Ronan Paddison (Ed.), Handbook of Urban Studies (pp. 14-35), London: Sage Publications.

Gökçe, B. (1977). Gecekondu Gençliği. Ankara: Hacettepe Üniversitesi Yayınları.

Harvey, D. (2012). Sermayenin Mekânları. Başak Kıcır, Deniz Koç, Kıvanç Tanrıyar ve Seda Yüksel (Çev.), İstanbul: Sel Yayıncılık.

Huot, J. L., Thalmann J. P. \& Valbelle D. (2000). Kentlerin Doğuşu. (Çev.) Ali Bektaş Girgin, Ankara: İmge Kitabevi Yayınları.

İspir, E. (1982). Kentleşme, Metropolitan Alan ve Yönetimi. Ankara: Ankara İktisadi ve Ticari İlimler Akademisi Yayınları.

Kartal, S. K. (1983). Kentlileşmenin Ekonomik ve Sosyal Maliyeti. Amme İdaresi Dergisi, 16 (4), 92-110. 
Kaypak, Ş. \& Bimay, M. (2016). Suriye Savaşı Nedeniyle Yaşanan Göçün Ekonomik ve SosyoKültürel Etkileri: Batman Örneği. Batman Üniversitesi Yaşam Bilimleri Dergisi, 6 (1), 84-110.

Kaypak, Ş., Bimay, M. \& Yılmaz, V. (2019). Belediyelerin Sürdürülebilir Kentleşme Sürecinde Çevrenin Korunmasına Yönelik Faaliyetleri: Batman Belediyesi Örneği. 12. Uluslararası Kamu Yönetimi Sempozyumu (KAYSEM 12) 25-27 Ekim 2018 Bildiri E-Kitabı, H. Yaylı (Ed.), Türkiye'de Toplum, Yerleşim Ve Yönetim Tartışmaları (ss.180-191), Kırıkkale: Kırıkkale Üniversitesi.

Kıray, M. B. (1998). Kentleşme Yazıları. İstanbul: Bağlam Yayınları.

Lefebvre, H. (2013). Kentsel Devrim. Selim Sezer(Çev.), İstanbul: Sel Yayıncılı.

Maunier R. (1910). The Definition of the City. American Journal of Sociology, 15 (4), 536548.

Mumford, L., (2013). Tarih Boyunca Kent. Gürol Koca(Çev.), (2. Bask1), İstanbul: Ayrınt1 Yayinlar1.

Mutlu, A. \& Batmaz N..(2013). Türkiye'de Kent Hakkı. Ankara: Orion Kitabevi.

Ortaylı, İ. (1974). Tanzimattan Sonra Mahalli İdareler. Ankara: TODAİE Yayınları.

Ortaylı, İ. (1995). Devraldığımız Miras. Yeni Türkiye, Yönetimde Yeniden Yapılanma Özel Saylsi, 1(4), 552-558.

Ozankaya, Ö. (1975). Toplumbilim Terimler Sözlüğü. Ankara:T.D.K. Yayınları.

Pirene, H. (2000). Ortaçă̆ Kentleri: Kökenleri ve ticaretin Canlanması, Şadan Karadeniz(Çev.), 2. Baskı, İstanbul: İletişim Yayınları.

Punch, K. F. (2011). Sosyal Araştırmalara Giriş/Nicel ve Nitel Yaklaşımlar. Dursun Bayrak, H. Bader Arslan \& Zeynep Akyüz(Çev.), Ankara: Siyasal Kitapevi.

Saunders, P. (2013). Sosyal Teori Kentsel Sosyoloji. Songül Doğru Getir(Çev.), Nihal Ekin Erkan(Ed.), İstanbul: İdeal Kültür Yayıncılık.

Sezal, İ. (1997). Göçler ve Şehirleşemeyen Şehirler. II. Ulusal Sosyoloji Kongresi Bildiriler Kitabı (Mersin-Kasım1996), Ankara: DİE (Yayın No: 2046) ve Sosyoloji Derneği (Yayın No: 5) Ortak Yayını, 147-151.

Sjoberg, G. (2002). Sanayi Öncesi Kenti. Ayten Alkan ve Bülent Duru (Der. ve Çev.), 20. Yüzyıl Kenti (ss. 41-42), Ankara: İmge Kitabevi Yayınları.

Şenyapı11, Ö. (1981). Kentleşemeyen Ülke, Kentlileşen Köylüler. ODTÜ Mimarlık Fakültesi, Ankara: Ara-Yayınları.

Tatlıdil, E . (2009). Kent ve Kentli Kimliği; İzmir Örneği. Ege Akademik Bakış, 9 (1), 319-336. Do1:10.21121/Eab.2009119745.

Tekeli, İ. (1991). Bir Kentin Kimliği Üzerine Düşünceler. Kent Planlaması Konuşmalarl, Ankara: TMMOB Mimarlar Odası Yayınları,79-89.

Tekeli, İ. (1998). Türkiye'de İç Göç Sorunsalı Yeniden Tanımlama Aşamasına Geldi. Ahmet İçduygu ve Diğerleri(Ed.), Türkiye’de İç Göç (7-21), İstanbul: Türkiye Ekonomik ve Toplumsal Tarih Vakfı Yayınları. 
Tosics, I. (1997). Habitat II Conference on Human Settlements, Istanbul, June 1996. International Journal of Urban and Regional Research, 21 (2),366-72.

Vergin, N. (1986). Hızlı Şehirleşmenin Sosyolojik ve Siyasal Sonuçları. Hızlı Şehirleşmenin Yarattığı Ekonomik ve Sosyal Sorunlar, İstanbul: SİSAV Yayınları, 27-52.

Weber. M. (2003). Şehir, Modern Kentin Oluşumu. Musa Ceylan (Çev.), İstanbul: Bakış Yayınlar1.

Wirth, L. (2002). Bir Yaşam Biçimi Olarak Kentlileşme. Ayten Alkan ve Bülent Duru (Der. ve Çev.), 20. Yüzyıl Kenti(ss.77-106), Ankara: İmge Kitabevi Yayınları. 